Chirurgia (2021) 116: 424-430

No. 4, July - August

Copyright@ Celsius

http://dx.doi.org/10.21614/chirurgia.116.4.424

\title{
A Single Center Experience in Liver Resection and Ablative Techniques: An Analysis of Six Years
}

\author{
Dragoș Chiriță', Alexandru Martiniuc'", Doina Hrehoreț², Nicolae Boleac', lanoș Pahomea', Victor Constantinică', \\ Daniela Tabacelia ${ }^{3}$, Mădălina Greere ${ }^{3}$, Cristina Radu³, Ana Stănilă', Radu Poenaru', Cristina Maria Amza', \\ Radu Dumitru4, Florentina Nițu${ }^{4}$, Adelina Birceanu ${ }^{5}$, Cristina losiff ${ }^{5}$ Laura Popa ${ }^{6}$, Narcis Copcă', Cezar Stroescu ${ }^{1}$
}

\author{
${ }^{1} 2^{\text {nd }}$ Department of Surgery, Sfânta Maria Clinical Hospital Bucharest, Romania \\ ${ }^{2}$ Fundeni Clinical Institute, Dan Setlacec Center of General Surgery and Liver Transplant, Bucharest, Romania \\ ${ }^{3}$ Department of Gastroenterology, Sfânta Maria Clinical Hospital Bucharest, Romania \\ ${ }^{4}$ Department of Radiology, Sfânta Maria Clinical Hospital Bucharest, Romania \\ ${ }^{5}$ Department of Pathology, Sfânta Maria Clinical Hospital Bucharest, Romania \\ ${ }^{6}$ Department of Anesthesiology and Intensive Care Unit, Sfânta Maria Clinical Hospital Bucharest, Romania
}

*Corresponding author: Alexandru Martiniuc MD $2^{\text {nd }}$ Department of Surgery Stânta Maria Clinical Hospital Bucharest, Romania

E-mail: alex.martiniuc@gmail.com

\section{Rezumat \\ Experiența centrului în tehnicile chirurgicale și ablative pentru tratamentul tumorilor hepatice}

Introducere: Prezentăm experiența departamentului nostru în abordarea tumorilor hepatice atât chirurgical cât şi prin procedee ablative, experiență acumulată în 6 ani.

Metoda: S-a efectuat o analiză retrospectivă pe baza de date a secției unde au fost introduşi prospectiv pacienții la care s-a practicat rezecții hepatice, ablație tumorală cu microunde (MWA), injectare cu alcool (PEI) sau TACE în perioada ianuarie 2014 decembrie 2020.

Rezultate: Au fost analizați 249 de pacienți, dintre care $273 \mathrm{cu}$ rezecții hepatice, 12 pacienți cu rezecții hepatice şi MWA, 9 pacienți cu MWA prin chirurgie deschisă, 12 pacienți cu MWA percutanat, 1 pacient cu TACE şi MWA, 1 pacient cu TACE şi PEI, 10 pacient cu TACE şi 2 pacienți cu PEI.

Concluzii: Managementul pacienților cu afecțiuni hepatice trebuie efectuat în centre care pot să asigure o gamă cât mai variată de mijloace terapeutice atât de diagnostic cât şi de tratament. Chirurgia hepatică efectuată în centre cu experiență şi volum mare oferă rezultate favorabile privind mortalitatea şi morbiditatea. 
Cuvinte cheie: chirurgie hepatică, ablație cu microunde, TACE

\begin{abstract}
Introduction:We present our 6-year experience with liver surgery and ablative techniques.

Method: An observational retrospective analysis from a prospectively maintained database was performed in our department. All the patients with liver resection, liver resection combined with intraoperative ablative techniques and percutaneous ablative techniques were included from January $1^{\text {st }} 2014$ to December $31^{\text {st }} 2020$.

Results: There were 249 patients analyzed: 273 patients with liver resection, 12 patients with liver resection combined with intraoperative MWA, 9 patients with open surgery MWA, 12 patients with percutaneous MWA, 1 patient with TACE and MWA, 1 patient with TACE and PEI, 10 patients with TACE, and 2 patients with PEI.

Conclusion:Liver disease should be managed in specialized centers which can offer a wide range of therapeutic options. With the improvement of the surgical technique and perioperative care, including optimized postoperative complication management, and carried out by well-trained surgeons, liver surgery can be performed with low mortality and acceptable morbidity.
\end{abstract}

Kew words: liver surgery, microwave ablation, TACE

\section{Introduction}

Liver resection is the treatment of choice for most benign and malignant hepatic lesions. This special type of surgery has evolved from a rare procedure with high mortality to routine surgery with an operative mortality risk of under $2 \%$ (1). The addition of other new generation therapeutic image guided minimally invasive techniques has increased the treatment optimization for patients with liver disease. Individualized multi-modal treatment is now performed in multidisciplinary settings in specialized centers (2).

The positive impact between high volume and outcome has been demonstrated in many surgical fields $(3,4)$. A modern hepato-biliary center has to be able to offer the patient a wide range of therapeutic options from a simple liver biopsy to complex liver surgery and liver transplantation.

The aim of this present study is to evaluate our 6-year experience with liver resections and ablative techniques.

\section{Patients and Methods}

An observational retrospective analysis from a prospectively maintained database was performed in our department. All the patients with liver resection, liver resection combined with intraoperative ablative techniques and percutaneous ablative techniques were included from January $1^{\text {st }} 2014$ to December $31^{\text {st }} 2020$.

The variables studied included age, sex, relevant medical history, comorbidities, indication for resection, extension of resection, associated resections, operative time, transfusion requirements, data regarding postoperative complications, length of stay, and data regarding the pathology report consisting of tumor size, stage, nodal status, and margin status.

All the liver resections were performed by open approach. Anatomical liver resections were defined according to Brisbane terminology (5). For the majority of liver metastases, a wedge resection was performed. The term "non-anatomical hepatectomy" or "atypical hepatectomy" was utilized when partial resec- 
tion of at least three contiguous segments was performed. Resections were considered minor when they involved one or two segments, and major when they involved more than two segments (left hepatectomy, right hepatectomy, trisectionectomy). For extended resections, volumetric assessment was performed by an expert radiologist.

Postoperative complications were reported according to the Clavien-Dindo grading system (6). Minor complications were defined as grades I-II, and major complications as grades III-IV. The bile fistula was defined and reported according to the International Study Group of Liver Surgery (ISGLS) definition (7).

Regarding the ablative techniques, our department uses the Evident Medtronic Microwave Ablation system (MWA) for intraoperative procedures, and the Emprint System for percutaneous ablation. The length of the antennas was $17 \mathrm{~cm}$ and $20 \mathrm{~cm}$ with the active tip of $3.7 \mathrm{~cm}$ and $3 \mathrm{~cm}$. The microwave power delivered was standardized for every lesion depending on the tumor size. Needle tract ablation was performed every time. In the percutaneously treated group as well as the intraoperatively treated one the MWA was performed under ultrasound guidance.

The other minimally invasive procedures performed were transarterial chemoembolization (TACE) and percutaneous ethanol injection (PEI). We must mention that our angiography and interventional radiology department was opened in April 2019. Tumor response was assessed according to the modified Response Evaluation Criteria in Solid Tumors (m-RECIST) by CT or MRI by an expert radiologist (8).

\section{Results}

During the study period, 249 patients were included for analysis. There were 135 male, and 114 female patients, the median age was 61 . The number and type of procedures are presented in Table 1. The types of liver resections are illustrated in Table 2. The indications for liver resection and ablation are presented in Table 3. We divided and analyzed the patients according to the diagnosis.
Table 1. Patients treated in our department in the study period

\begin{tabular}{lr}
\hline Liver resection & 273 \\
\hline Liver resection combined with intraoperative MWA & 12 \\
\hline Open surgery MWA & 9 \\
\hline Percutaneous MWA & 12 \\
\hline TACE combined with MWA & 1 \\
\hline TACE combined with PEI & 1 \\
\hline TACE & 10 \\
\hline PEI & 2 \\
\hline Total number of patients & 249
\end{tabular}

MWA: microwave ablation; TACE: transarterial chemoembolization;

PEl: percutaneous ethanol injection

Table 2. Type of resection

\begin{tabular}{lr}
\hline Type of resection & $\mathbf{n}$ \\
\hline Total procedures & 285 \\
\hline Wedge resections & 172 \\
\hline Non-anatomical hepatectomies & 53 \\
\hline Left lateral sectionectomy & 10 \\
\hline Right posterior sectionectomy (sg 6-7) & 9 \\
\hline Right anterior sectionectomy (sg 5-8) & 4 \\
\hline Central hepatectomy (4,5,8) & 1 \\
\hline Left hepatectomy & 3 \\
\hline Extended left hepatectomy & 4 \\
\hline Right hepatectomy & 6 \\
\hline Extended right hepatectomy & 2 \\
\hline Right hepatectomy + segment 1 & 1 \\
\hline Caudate lobectomy & 2 \\
\hline ALPPS (first and second stage) & 1 \\
\hline Other liver procedures & 17 \\
\hline
\end{tabular}

Table 3. Patients with malignant liver disease

\begin{tabular}{lr}
\hline Malignant tumors & 204 \\
Colorectal metastases & 96 \\
Non-colorectal metastases & 52 \\
Hepatocellular carcinoma & 39 \\
Cholangiocarcinoma & 5 \\
Gallbladder cancer & 5 \\
Klatskin tumors & 3 \\
Hepatic invasion of other type of cancer & 4 \\
\hline
\end{tabular}

\section{Patients with Liver Metastatic Disease (148 patients)}

There were 96 patients treated for colorectal liver metastases. The mean liver tumor size was $32 \mathrm{~mm}$ (min $3 \mathrm{~mm}$, max $200 \mathrm{~mm})$. In 26 patients, the liver resection was performed simultaneously with the primary colorectal cancer. The highest number or liver resections for metastases per patient was 9 . In 2 


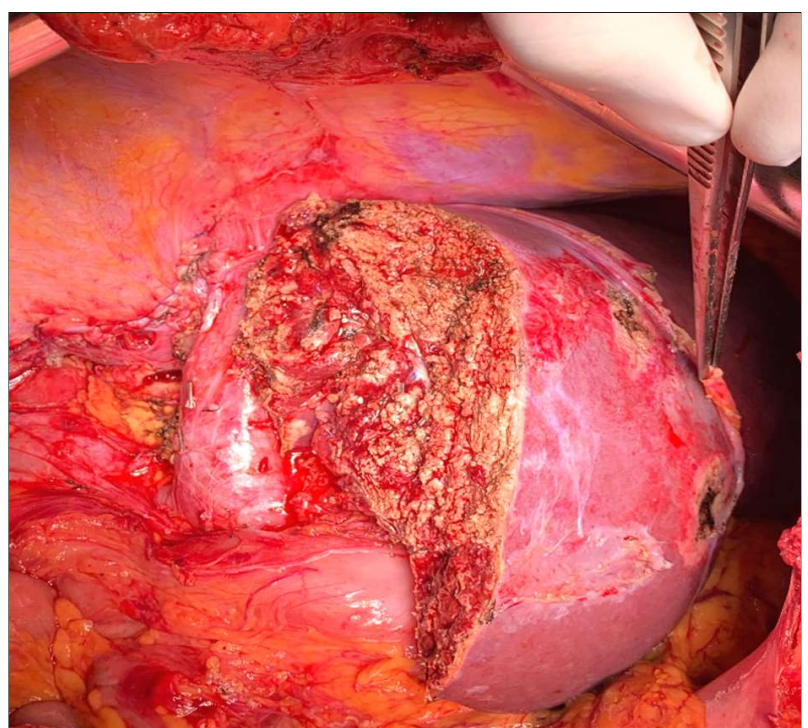

Figure 1. Right hemihepatectomy for liver metastases from colon cancer

patients, a liver first approach was performed. Major resections were performed in 7 patients. Fig. 1 illustrates a right hemihepatectomy and Fig. 2 a central hepatectomy for colon cancer liver metastases.

In 9 patients, liver resection was combined with microwave ablation under ultrasound guidance. The highest number of intraoperative thermal ablations per patient was 4 . In 7 patients, microwave ablation was performed by laparotomy because of difficult percutaneous approach or for deep parenchyma/ centrally located metastases not feasible for a parenchyma sparing resection.

In 52 patients, liver resection was performed for non-colorectal liver metastases. There were 4 patients with neuroendocrine tumors, 22 biliopancreatic tumors, 4 ovarian cancer, 11 gastric cancer, 8 breast cancer, 1 esophageal squamous cell tumor, 1 cervix squamous cell tumor, and 1 malignant melanoma. In patients who underwent liver resections, R0 was achieved in 130 cases, and $\mathrm{R} 1$ in 11 cases (including 7 patients with R1-vascular). In 10 patients, liver resection was an associated procedure for other abdominal major resection: pancreaticoduodenectomy one patient, distal pancreatectomy one, total gastrectomy six patients

The overall morbidity in this group of

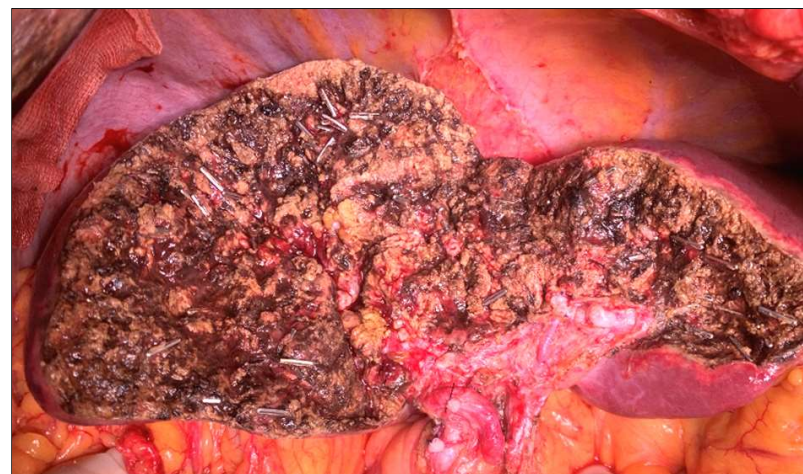

Figure 2. Central hepatectomy for liver metastases from colon cancer

Table 4. Clavien-Dindo grades for patients with liver metastasis resections

\begin{tabular}{lc}
\hline Complication grade & Number of patients \\
\hline II & 22 \\
\hline IIIA & 11 \\
\hline IIB & 4 \\
\hline IVA & 5 \\
\hline IVB & 2 \\
\hline$V$ & 1 \\
\hline
\end{tabular}

Table 5. Complications for patients with liver metastasis resections

\begin{tabular}{lc}
\hline Complications & Number of patients \\
\hline Liver-related complications & \\
Bile leak & 13 \\
Cut-surface abscess & 8 \\
Cut-surface hematoma & 1 \\
Liver failure & 1 \\
Hemoperitoneum & 2 \\
Intra-abdominal abscess & 3 \\
\hline Systemic complications & \\
MODS & 4 \\
ARDS & 6 \\
Cardiorespiratory arrest & 4 \\
Respiratory dysfunction & 5 \\
Superior digestive hemorrhaging & 2 \\
Sepsis & 4 \\
Renal dysfunction & 4 \\
Pleural effusion & 4 \\
\hline Other surgical-related complications & \\
Perforated ulcer & 1 \\
Bowel occlusion & 2 \\
Wound infection & 12 \\
Peritonitis & 2 \\
Wound hematoma & 4 \\
\hline
\end{tabular}

patients was $33 \%$. The in-hospital mortality in this group of patients was $2.7 \%$. The Clavien-Dindo grading and specific complications are presented Tables 4 and 5. 


\section{Patients with Hepatocellular Carcinoma (39 patients)}

There were 9 liver resections performed in patients with confirmed CHILD A cirrhosis, and 7 resections for hepatocellular carcinoma not associated with liver disease. The mean liver tumor size was $64.53 \mathrm{~mm}$ ( $\min 10 \mathrm{~mm}$, $\max 120 \mathrm{~mm}$ ). TNM staging was: 5 patients with T1N0, 2 patients with T2N0, 6 patients with T2N1, 2 patients with T3N1, and one patient with $\mathrm{T} 4 \mathrm{~N} 1$. Regarding the resection margin, $\mathrm{R} 0$ was achieved in 14 cases, $\mathrm{R} 1$ in 2 cases. The postoperative mortality was $2.56 \%$, and morbidity was $17.94 \%$. The Clavien-Dindo and specific complications are presented in Tables 6 and 7 .

In 10 patients with hepatocellular carcinoma, TACE was performed. In one case, TACE was associated with percutaneous MWA, and in another case, TACE was associated with PEI. Percutaneous MWA for HCC was performed in 10 cases. There was no mortality in this group of patients.

In one case, open surgery MWA was utilized for a ruptured hepatocellular carcinoma on a CHILD C patient to achieve hemostasis with good result. The patients were operated on in another hospital for hemoperitoneum from a rupture hepatocellular carcinoma, perihepatic packing was performed, and the patients were transferred to our department.

\section{Patients with Peripheric Cholangiocarcinoma (5 patients)}

In this group of patients, there were 2 minor hepatectomies and 3 patients with major hepatectomies. In one patient, we performed an extended right hemihepatectomy with portal vein resection (Fig. 3) and reconstruction with a colangio-jejunostomy with 3 ducts (s2, s3, s4). TNM staging: 1 patient with T2N0 G2, 1 patient with T2N1 G2, 1 patient with T3N0 G2, 1 patient with T3N2 G3, 1 patient with T4N0 G2. R0 was achieved in all cases.

Although there was no mortality in this group of patients, the morbidity was $41 \%$. One patient required re-laparotomy for a cut-
Table 6. Clavien-Dindo grades for patients with hepatocellular carcinoma resections

\begin{tabular}{lc}
\hline Complication grade & Number of patients \\
\hline I & 4 \\
\hline III & 1 \\
\hline IIIB & 1 \\
\hline IVA & 0 \\
\hline IVB & 0 \\
\hline V & 0 \\
\hline
\end{tabular}

Table 7. Complications for patients with hepatocellular carcinoma resections

\begin{tabular}{lc}
\hline Complications & Number of patients \\
\hline Liver-related complications & \\
Bile leak & 2 \\
Cut-surface abscess & 2 \\
$\quad$ Liver failure & 1 \\
\hline Systemic complications & \\
MODS & 1 \\
ARDS & 2 \\
Cardiorespiratory arrest & 1 \\
Respiratory dysfunction & 2 \\
Renal dysfunction & 1 \\
\hline Other surgical-related complications & \\
$\quad$ Wound hematoma & 4 \\
\hline
\end{tabular}

surface hematoma. There was one patient with post-hepatectomy liver failure with ascites that needed prolonged ICU management. There were 3 grade Abiliary fistulas, and one grade B.

\section{Patients with Klatskin Tumors (3 patients)}

There were 2 patients with Klatskin IIIA with

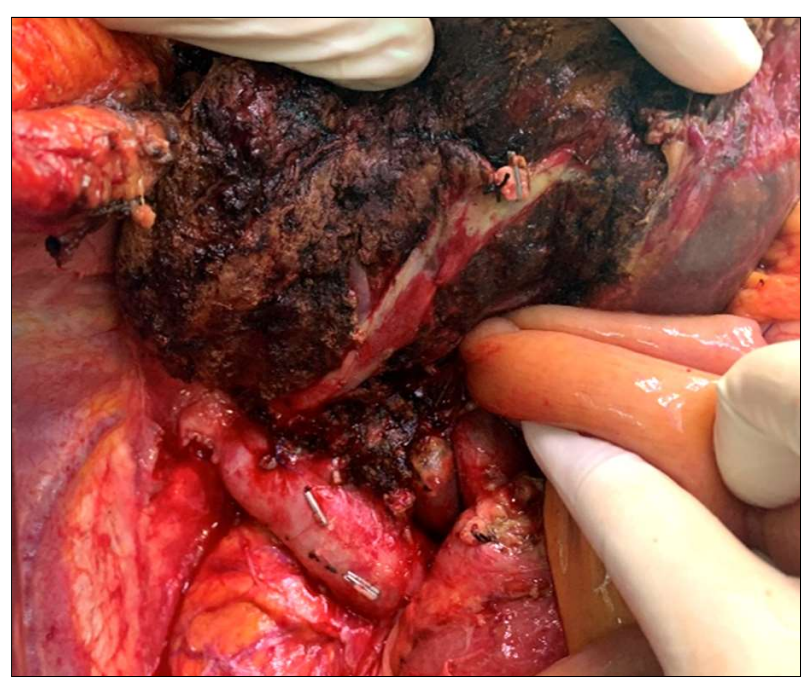

Figure 3. Right extended hepatectomy with portal vein resection 
common bile duct resection en-bloc with a right hepatectomy with caudate lobectomy, and one patient with a Klatskin II with tumor with a left hepatectomy because of left hepatic artery invasion. One patient died due to septic complication after a grade $\mathrm{C}$ biliary fistula.

TNM staging: 1 patient with T2N0 G2, 2 patients with T3N1 G2. R0 was achieved in all cases.

\section{Patients with Gallbladder Cancer (5)}

In 3 patients, a radical cholecystectomy with partial resection of segments $\mathrm{IVb}-\mathrm{V}$ was performed. In one patient a right hepatectomy with common bile duct resection and segmental portal vein resection was performed (the gallbladder tumor was extended to the common bile duct and the right portal vein). In one patient, a cholecystectomy with an atypical IV-V-VI segments resection associated with transverse colon resection was performed.

TNM staging: 1 patient with T2N1 G2, 2 patients with T3N1 G2, 2 patients with T4N1 G2. R0 was achieved in 4 cases, and $\mathrm{R} 1$ in 1 case.

There were 2 grade $\mathrm{A}$, and one grade $\mathrm{B}$ biliary fistula. One patient died due to post-hepatectomy liver failure with septic complications from a grade $\mathrm{C}$ biliary fistula.

\section{Patients with Liver Resection for Benign Disease (45 patients)}

The surgical indications for benign disease are described in Table 8. Complications were encountered in 10 cases, morbidity $22.2 \%$.

Table 8. Patients with benign liver disease

\begin{tabular}{lr}
\hline Benign lesions & 45 \\
Hydatid cyst & 12 \\
Hemangioma & 10 \\
Inflammatory pseudotumor & 10 \\
Non-specific inflammation & 5 \\
Focal nodular hyperplasia & 3 \\
Adenoma & 2 \\
Sarcoidosis nodules & 1 \\
Fibrosis & 1 \\
Essential cyst & 1 \\
\hline
\end{tabular}

Clavien-Dindo I - 7 cases, II- 1 case, IIIB- 1 case. Grade A biliary fistula in 4 cases, cut-surface hematoma in 2 cases, wound complications in 2 cases.

\section{Discussion}

Centralization of complex hepatobiliary procedures is associated with increased quality of care $(9,10)$. Indeed, not only the decision-making process in establishing the treatment options for patients with liver disease but also the optimization of postoperative/ postprocedural complications is of utmost importance (11). Multi disciplinarity is the key factor in successful management for patients with liver disease (12). Well-trained hepato-biliary surgeons, interventional radiologists, and hepatologists, dedicated pathologists, oncologists, and anesthesiologists are all equally important when treating patients with complex liver disease (13).

We presented our 6-years' experience in hepato-biliary surgery with good postoperative results (13). Since the establishment in our hospital of the 2nd national liver transplantation program in 2014 the number of liver resections has been increasing yearly. With the addition of the new angiography department, our hospital can offer a wide range of therapeutic options for patients with complex liver disease.

In our study, the majority of resected lesions was malignant $(72.54 \%)$; among these, colorectal liver metastases were the most frequent tumors $(47.05 \%)$, followed by non-colorectal metastases (25.49\%), and hepato-cellular carcinoma (19.11\%). Benign tumors represented $15.78 \%$ of resected cases, hydatid cyst and hemangioma being the most frequent (4.21\%).

Liver resection has been associated with high morbidity and mortality. The reported morbidity ranged from $16.2 \%$ to $81 \%$ (14-17). This range is partially due to the heterogeneity of the published series, with major differences in indication, extension of liver resection and definition of postoperative complication. Our morbidity rate was $28.53 \%$ following liver resection. 
For the classification of complications after liver resections we used the Clavien-Dindo grading system (6). In the case of liver resections for metastases, the complication rate was $33.10 \%$, while for liver resections for primary tumors it was $17.94 \%$. The most frequent complication was biliary leak, in $4.48 \%$, similar to major international centers and followed by intra-abdominal sepsis rate in $4.10 \%$, as compared to $6.9 \%$ and $3 \%$ in the reports of Miyagawa et al. (18) and Lai et al. (19).

Given the success of the national online prospective electronic database for pancreatic resections established in Romania, we hope that a similar registry for liver resection will soon be available for data reporting in order to compare and improve our results to international experience.

\section{Conclusion}

Liver disease should be managed in specialized centers which can offer a wide range of therapeutic options. With the improvement of the surgical technique and perioperative care, including optimized postoperative complication management and carried out by well-trained surgeons, liver surgery can be performed with low mortality and acceptable morbidity.

\section{Conflict of Interest}

The authors declare no conflicts of interests.

\section{Ethics Approval}

The study was approved by the institution's ethics committee.

\section{References}

1. Weledji EP. Centralization of liver cancer surgery and impact on multidisciplinary teams working on stage IV colorectal cancer. Oncol Rev. 2017;11(2):331. eCollection 2017 Jun 14.

2. Graf D, Vallböhmer D, Knoefel WT, Kröpil P, Antoch G, Sagir A, et al. Multimodal treatment of hepatocellular carcinoma. Eur J Intern Med. 2014; 25(5):430-7.

3. Fong Y, Gonen M, Rubin D, Radzyner M, Brennan MF. Long-term survival is superior after resection for cancer in high-volume centers. Ann Surg. 2005; 242(4):540-4; discussion 544-547.

4. Complex Adult and Pediatric Surgery [Internet]. Hospital and Surgery Center Ratings I Leapfrog Group. [cited 2021 Aug 8]. Available from: https://ratings.leapfroggroup.org/measure/hospital/complex-adult-andpediatric-surgery

5. Strasberg SM, Belghiti J, Clavien P-A, Gadzijev E, Garden JO, Lau W-Y, et al. The Brisbane 2000 Terminology of Liver Anatomy and Resections. HPB. 2000;2(3):333-9.

6. Clavien PA, Barkun J, de Oliveira ML, Vauthey JN, Dindo D, Schulick RD, et al. The Clavien-Dindo classification of surgical complications: five-year experience. Ann Surg. 2009;250(2):187-96.

7. Koch M, Garden OJ, Padbury R, Rahbari NN, Adam R, Capussotti L, et al. Bile leakage after hepatobiliary and pancreatic surgery: A definition and grading of severity by the International Study Group of Liver Surgery. Surgery. 2011;149(5):680-8.

8. Gregory J, Dioguardi Burgio M, Corrias G, Vilgrain V, Ronot M. Evaluation of liver tumour response by imaging. JHEP Reports. 2020;2(3):100100.

9. Glasgow RE, Showstack JA, Katz PP Corvera CU, Warren RS, Mulvihill SJ. The relationship between hospital volume and outcomes of hepatic resection for hepatocellular carcinoma. Arch Surg. 1999;134(1):30-5.

10. Franchi $E$, Donadon M, Torzilli $G$. Effects of volume on outcome in hepatobiliary surgery: a review with guidelines proposal. Glob Health Med. 2020; 2(5):292-7.

11. Jin S, Fu Q, Wuyun G, Wuyun T. Management of post-hepatectomy complications. World J Gastroenterol. 2013;19(44):7983-91.

12. Esnaola NF, Meyer JE, Karachristos A, Maranki JL, Camp ER, Denlinger CS Evaluation and management of intrahepatic and extrahepatic cholangiocarcinoma. Cancer. 2016;122(9):1349-69.

13. Torzilli G. Viganò L, Giuliante F, Pinna AD. Liver surgery in Italy. Criteria to identify the hospital units and the tertiary referral centers entitled to perform it. Updates Surg. 2016:68(2):135-42.

14. Nagino M, Kamiya J, Uesaka K, Sano T, Yamamoto H, Hayakawa N, et al. Complications of hepatectomy for hilar cholangiocarcinoma. World J Surg. 2001;25(10):1277-83.

15. Hoffmann K, Hinz U, Stravodimos C, Knoblich T, Schön MR, Büchler MW, et al. Risk assessment for liver resection. Surgery. 2018:164(5):998-1005.

16. Madhavan S, Shelat VG, Soong S-L, Woon WWL, Huey T, Chan YH, et al. Predicting morbidity of liver resection. Langenbecks Arch Surg. 2018; 403(3):359-69.

17. Virani S, Michaelson JS, Hutter MM, Lancaster RT, Warshaw AL, Henderson WG, et al. Morbidity and Mortality after Liver Resection: Results of the Patient Safety in Surgery Study. Journal of the American College of Surgeons. 2007;204(6):1284-92.

18. Miyagawa S, Makuuchi M, Kawasaki S, Kakazu T. Criteria for safe hepatic resection. Am J Surg. 1995;169(6):589-94.

19. Lai EC, Fan ST, Lo CM, Chu KM, Liu CL, Wong J. Hepatic resection for hepatocellular carcinoma. An audit of 343 patients. Ann Surg. 1995;221(3): 291-8. 